\title{
THE SHIFT IN FIRMS' RELIANCE ON DEBT SOURCES
}

\section{TU HO*}

Auckland University of Technology, Auckland, New Zealand

* Corresponding Author: Tu Ho, Lecturer at Auckland University of Technology, New Zealand. 疅+099219999 ext. $5826 \bowtie$ ctho@aut.ac.nz

\begin{abstract}
Structural changes in capital market and information innovations have altered characteristics of debt sources, make them favourable to firms. This could possibly lead to a shift in firms' reliance on debt sources. Using a unique data set of debt mix of 1,100 U.S. non-financial firms, I conduct data analysis to reveal changes in firms' preference for different debt sources over a decade from 2004 to 2014. I find that bank debt remains the most common source of borrowing, followed by public debt and finally private placement debt. In addition, over time, firms have become more reliant on bank and public debt while less reliant on private placement debt. This pattern is consistent across different industries.
\end{abstract}

Keywords: Capital Markets, Financial Markets, bank debt, debt sources

\section{Introduction}

Firms can generally borrow from three main sources: debt issuance on financial markets, banks, and private lenders. These sources are distinct in various aspects that make them more or less desirable to firms depending on their needs and characteristics. Over the years, structural changes in capital markets and technology development have altered the distinctive characteristics of these debt sources (Boot and Thakor, 2000; Dinc, 2000; Gande and Sauders, 2012; Petersen and Rajan, 2002; Tracey and Carey, 2000). This raises an interesting question on how firms' preferences for debt sources have changed over time.

Observing changes in firms' reliance on different debt sources can partly reveal the answer to this question. This article uses a unique dataset of debt sources available to the U.S firms to carry out some data analysis on changes in the popularity of bank, public and private placement debt and in debt ownership structure over a ten-year period from 2004-2014. In general, I find that firms consistently rely the most on bank debt to finance their operations, followed by public debt and finally private placement debt. Over time, firms' reliance on bank and public debt tend to increase while the opposite pattern is observed for private placement debt.

\section{Data}

I hand collect debt source data for a sample of 1,100 randomly chosen U.S. nonfinancial firms in the three different years: 2004, 2009 and 2014. The random sample is based on the Compustat firm list from 2004. The dataset covers information on the three 
main borrowing sources that have been discussed in literature, namely bank debt, public debt, and private placement debt. The final dataset consists of 2,707 firm year observations for 1,100 US non-financial firms. The number of firms gradually decreases from 1,100 in 2004, to 894 in 2009 and finally to 713 in 2014.1

\section{Analysis and findings}

In this section, I conduct an analysis to reveal changes in firms' reliance on different debt sources over time. First, I provide an overall picture of how firms choose and rely on different types of lenders. To do so, I calculate the percentage of firms that has outstanding balance from a certain source to proxy its popularity and the proportion of that source to proxy how much firms rely on it. The second part focuses on three main debt sources only and their characteristics.

The popularity of bank, public and private placement debt sources

Graph 1 shows the percentage of firms that have outstanding balance of each debt source. Consistently, I find that bank debt remains the most popular, followed by public debt issuance and finally private placement. Among three main sources, bank debt is the most popular source of debt financing with more than $80 \%$ of the sample firms using or having financing agreements with banks. Public debt is the second with around $36 \%$ of firms having outstanding public bonds while private placement debt is the least popular with less than $20 \%$ of firms having outstanding balance from this source ${ }^{2}$.

\section{Figure 1: Percentage of observations that have outstanding debt of a given source}

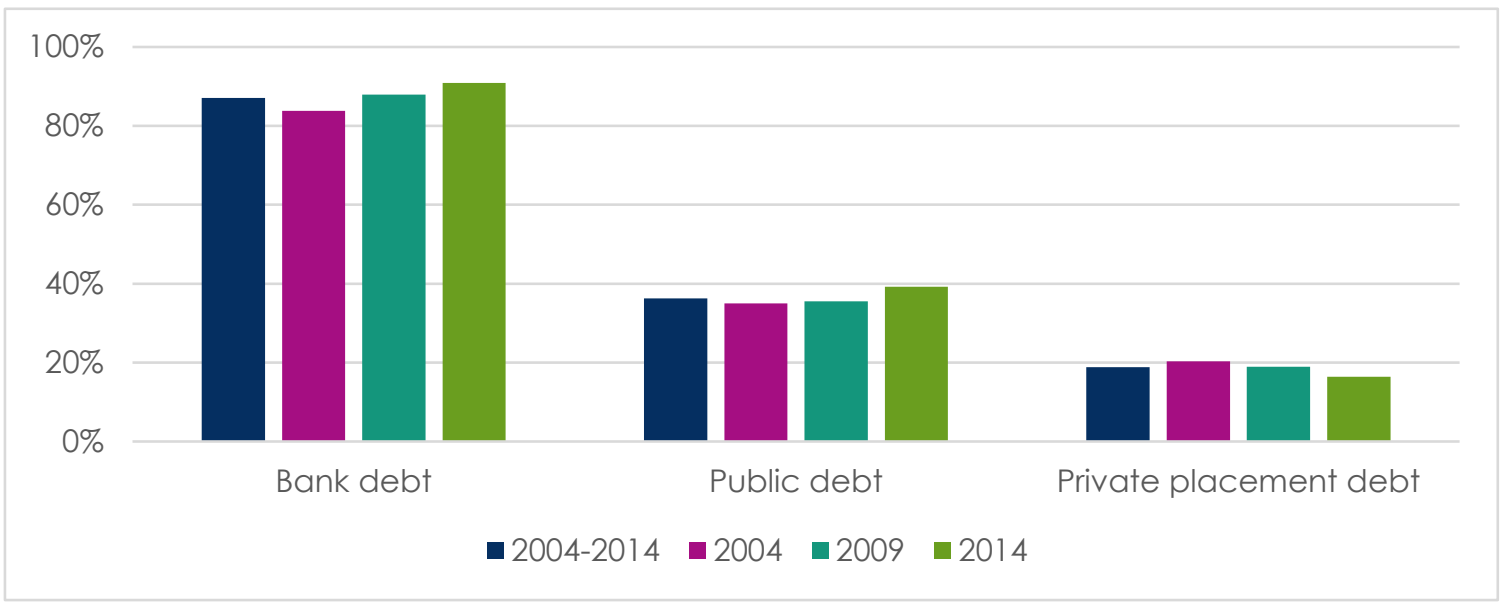

1 To check the representativeness of my sample, I compare the mean and medians of some firm characteristics between my sample and the whole market, including all US nonfinancial firms. I find that firm size, firm age and market-to-book ratios are relatively similar in both the entire sample and yearly subsamples. I further carry out the difference in mean tests also confirm that my sample can be considered as representative of the market and any patterns found in my data analysis are likely applicable to out-of-sample nonfinancial firms in the US market.

2 Since firms can simultaneously borrow from different debt sources, the sum of percentages of firms with outstanding balance from these sources can be greater than $100 \%$. 
Though the order of relative importance remains consistent over time, there is an upward trend in the number of firms using bank debt and issuing public debt on markets, in contrast to a decrease in that of private placement. Over the sample period, the popularity of bank and public debt has grown by $8.5 \%$ and $12.3 \%$, respectively, and that of private placement debt significantly dropped by $19 \%$.

\section{The proportions of bank, public and private placement debt sources}

Next, I analyse changes in each debt source by observing proportions of these sources used by firms over the sample period. Table 1 shows average and median proportions of different sources in total of outstanding debt for the full sample and the three subsamples. It can be observed that firms consistently rely the most heavily on bank debt (40.53\%) and public debt $(25.64 \%)$ to finance their business and the least on private placement debt $(10.92 \%)^{3}$. Among all debt sources, only bank debt has median proportion greater than zero, confirming the fact that bank debt is the only source that is used by more than $50 \%$ of firms in the sample as was also shown in Figure 1.

\section{Table 1: Debt ownership structure}

This table presents proportions of debt sources for the full sample and the three subsamples. BankPercent, PubPercent, PriPercent, ProPercent, LeasePercent, FinPercent, PartyPercent and OtherPercent are proportions of bank debt, public debt and private placement debt, program debt, capital lease, financial company debt, third party debt and other unclassified debt respectively in total outstanding debt. Measurement unit of all variables is in \%.

\begin{tabular}{lrrrrrrrr}
\hline & \multicolumn{2}{c}{ 2004-2014 } & \multicolumn{2}{c}{ 2004 } & \multicolumn{2}{c}{ 2009 } & \multicolumn{2}{c}{2014} \\
\cline { 2 - 8 } & Mean & Median & Mean & Median & Mean & Median & Mean & Median \\
\hline BankPercent & 40.53 & 23.77 & 36.92 & 16.87 & 41.32 & 25.49 & 45.13 & 34.12 \\
PubPercent & 25.64 & 0 & 24.84 & 0 & 24.73 & 0 & 28.01 & 0 \\
PriPercent & 10.92 & 0 & 12.76 & 0 & 10.35 & 0 & 8.77 & 0 \\
\hline
\end{tabular}

Moreover, the reliance of firms on both bank and public debt increases over time. Firms have $8.21 \%$ more bank debt and $3.17 \%$ more public debt in their debt ownership structure, equivalent to a growth of $22 \%$ and $12.8 \%$ in firms' reliance on these sources, respectively. Private placement debt, on the other hand, experienced a drop of $3.99 \%$ in proportion, which is converted to $31.3 \%$ decrease in firms' use of this source.

Since different industries with a distinctive business nature may prefer long- or short-term funding, they may have different preferences for bank, public and private placement debt. To make sure the observed pattern is not only present in certain industries, I split the sample into ten different industry groups and find consistent results in each of these groups. Moreover, I filter the samples into some subsamples with non-zero outstanding balance of each debt source to address the concern that averaging all numbers might not reflect the true picture. Consistent with the pattern found in the above section, I

\footnotetext{
3 My dataset covers information of nine borrowing sources, namely bank debt, public debt, private placement debt, programme debt, government debt, capital lease, financial company loans, third- or related-party borrowing, and finally other debt. This paper only analyses the three main sources widely discussed in the literature, namely bank debt, private placement and public debt. Therefore, the proportions of these three sources do not add up to $100 \%$ in Table 1.
} 
observe an upward trend in bank and public debt financing but a downward trend in private placement debt in each of these subsamples.

In general, banks remain the most important source of borrowing for the US firms, with the second-place public debt while private placement debt is the least important one in terms of both number of borrowers and the proportion in total debt. Moreover, over the ten-year period, firms tend to rely more on bank and public debt, and less on private placement debt. Since life insurance companies are dominant lenders in the private debt market (Pottier, 2007), a decrease in firms' preference to raise funds in this market might put these insurers in greater lending competition, which consequently can deteriorate credit quality and decrease bond yields.

\section{Conclusions}

This article uses a unique hand-collected dataset of debt sources to conduct some analysis on how firms' reliance on different sources of debt financing has changed among the US firms over time. The main finding is that among three main debt sources, bank debt remains the most important one, followed by public debt and lastly private placement debt. The difference between two ends of the scale of debt financing is getting wider in that firms are relying more and more on banks and less on private placement debt over the sample period. This finding is consistent across different industries and different subsamples of firms. I can see that there is a systematic shift in firms' choice of debt sources, and the interesting question is what factors are driving the trends. This systematic shift can hardly be explained by changes in macroeconomic factors since it is consistent through the pre- and post-global financial crisis periods. One possible explanation is that the structural changes in the debt markets and technology development have altered the distinction between debt sources, and thus made one more favourable than others as a borrowing source. It is well documented that firms with different level of information problem tend to seek fund from different debt markets. Those with the highest information asymmetry tend to rely on bank loans, while those with moderate informational problem rely more on private placement debt market and those with the lowest degree of information problem rely more on public debt. Recent innovations in information technology have allowed potential lenders to easily acquire information, which includes but is not limited to hard information about the credit quality of borrowers and access the data most of which was not available to public investors before (Petersen and Rajan, 2002; Tracey and Carey, 2000; DeYoung et al., 2011). This might have widened the entrance into public debt market and allowed more firms seeking long-term debt to access this source where they have more options at lower costs. In addition, the recent developments in the secondary loan market might contribute to the shift since it helps banks to share and reduce their credit risk and thus allowing firms to acquire bank debt more easily. Given these possible explanations, this shift is predicted to continue into near future. Further research on the link between capital market changes and the change in firms' debt mix is necessary to confirm the drivers of the shift. Understanding this link can be important to policy makers in regulating and implementing policies to ensure the sustainable and balanced development of the markets. 


\section{References}

Boot, A. W., \& Thakor, A. V. (2000). Can relationship banking survive competition? Journal of Finance, 55(2), 679-713.

Boyd, J., \& Prescott, E. (1986). Financial intermediary-coalitions. Journal of Financial Theory, 38, 211-232.

Carey, M., Prowse, S., Rea, J., \& Udell, G. (1993). The economics of the private placement market. Washington: Federal Reserve System.

Denis, D. J., \& Mihov, V. T. (2003). The choice among bank debt, non-bank private debt, and public debt: evidence from new corporate borrowings. Journal of Financial Economics, 70, 3-28.

DeYoung, R., Frame, W. S., Glennon, D., \& Nigro, P. (2011). The Information Revolution and Small Business Lending: The Missing Evidence. Journal of Financial Services Research, 39(1-2), 19-33.

Diamond, D. (1984). Financial intermediation and delegated monitoring. Review of Economic Studies, 51, 394-414.

Dinç, I. S. (2000). Bank reputation, bank commitment, and the effects of competition in credit markets. The Review of Financial Studies, (3). 781-812.

Fama, E (1985). What's different about banks? Journal of Monetary Economics, 15, 2937.

Gande, A., \& Sauders, A. (2012). Are banks still special when there is a secondary market for loans? Journal of Finance, 67(5), 1649-1684.

Leland, H., \& Pyle, D. (1977). Informational asymmetries, financial structure and financial intermediation. Journal of Finance, 32, 371-387.

Petersen, M., \& Rajan, R. (2002). Does distance still matter: the information revolution in small business lending. Journal of Finance, 57, 2533-2570.

Pottier, S. W. (2007). The Determinants of Private Debt Holdings: Evidence from the Life Insurance Industry. Journal of Risk \& Insurance, 74(3), 591-612.

Rajan, R., \& Winton, A. (1995). Covenants and collateral as incentives to monitor. Journal of Finance, 50, $1113-1146$.

Tracy, W., \& Carey, M. (2000). Credit risk rating systems at large U.S. banks. Journal of Banking and Finance, 24, 167-201.

Welch, I. (1997). Why is bank debt senior? A theory of asymmetry and claim priority based on influence costs. Review of Financial Studies, 10, 1203-1236. 